\title{
GEOLOGIC MAP OF THE MOUNT TYNDALL QUADRANGLE, CUSTER COUNTY, COLORADO
}

\author{
By M. R. Brock and Q. D. Singewald
}

Description of map units

Qa Alluvium and colluvium--unconsolidated, water-deposited gravel and sand mostly in drainage bottoms, detrital material accumulated in basins and on slopes by water or gravity, and residual soil; rarely thicker than few tens of feet.

Volcanic rocks:

T1 Limburgite--dikes cut volcanic rocks on south slope of Mount Tyndall. Dense, black porphyry contains augite and olivine phenocrysts in aphanitic groundmass of nepheline, analcite, and glass.

Tv Volcanic rocks undivided--extrusive and intrusive complex in southwest corner of quadrangle includes rhyolite, andesite, and trachyte; part of much larger complex of tuffaceous flows, small plutons, dikes, sills, breccia, and agglomerate that extends southward and westward beyond the quadrangle.

Tr Rhyolite porphyry--plug and six dikes near volcanic complex. White rhyolite with about 25 percent phenocrysts of quartz and sanidine in microcrystalline groundmass, locally vitrophyric.

Nonmetamorphosed intrusive and related rocks:

TEl Lamprophyre--about 2 dozen small dikes. Darkgray to black dike rock with conspicuous large $(1-5 \mathrm{~cm})$ grains of hornblende and biotite in fine-grained groundmass of biotite, hornblende, pyroxene, and feldspar. Some dikes contain analcite, and some contain sparse large black andesine phenocrysts.

TEp Porphyritic olivine and augite basalt and peridotite--black, fine- to medium-grained pyroxene-rich dike rocks with mafic phenocrysts; some contain analcite.

TEb Diabase and nonporphyritic basalt--abundant dikes, dark-gray to black, fine-grained and aphanitic rocks, chiefly plagioclase and pyroxene with subordinate olivine, amphibole, and less commonly, biotite; analcite basalt in part. Some basalts are devitrified glass.

Ea Hydrothermally altered rock--gneisses pervasively enriched in potassium, sodium, and $\mathrm{CO}_{2}$ outward from fractures are most extensive in northwest-trending fault zone across north half of quadrangle. Appearance and composition reflect or iginal rock: pink to red microcline prevails in altered granitic gneisses; albite, ferroan dolomite, sodium amphibole, and vermiculite prevail in brown and bluish-gray altered mafic rocks. Less commonly includes hematite, calcite, siderite, magnesite, epidote, chlorite, aegirite, and scapolite. Altered rock was intruded by youngest of syenite dikes.

€m Mafic syenite--numerous dikes, mostly in northeast part of quadrangle, and individual small plutons that form compound stock. Gray and pinkish-gray, biotite- and amphibole-rich syenite. Mafic minerals, including biotite, amphibole (commonly riebeckite), and rarely a egirite, consitute 10-25 percent of rock; remainder is mostly albite or microcline. Locally contains few percent of analcite and nepheline. One variant contains conspicuous phenocrysts of black andesine and approaches composition of lampprophyre. Mafic syenite also approaches in composition porphyritic and nonporphyritic analcite basalts. Some dikes are devitrified glass.

Es Quartz syenite and syenite--hundreds of dikes, mostly in north half of quadrangle, typically fine grained, trachytic, many are porphyritic; also several hundred individual bodies of predominantly medium-grained, granular syenite form compound stock which lies mostly north of quadrangle. Small satellite plug lies in sec. 5 near north boundary of quadrangle. Pink, brownish-pink, and light-gray rocks of mostly albite or albite plus potassium feldspar, less than 10 percent biotite and amphibole, and commonly sparse quartz.

Eb Explosion breccia--crudely elliptical half-milelong mass on north boundary of quadrangle and several smaller bodies in northern part of quadrangle. Compact, indur at ed, heterogeneous mixture of broken rock including gneisses, syenite, and analcite basalt, virtually devoid of igneous matrix. Poorly sorted angular tragments range in size from greater than a hundred feet across to dust-size material. Outer $1 / 4-1 / 2$ inch of fragments is enriched in biotite and albite. Emplacement followed earliest syenite; subsequent syenite intrusion removed part of breccia mass. 
€g Gabbro--several plugs and large dikes commonly 100-200 feet thick. Dense, fine- to mediumgrained, dark-gray rock with ophitic texture. Composed largely of plagioclase, augite, and olivine. Textural variants are diabase and basalt dikes. Most dikes weathered to negative relief.

Gneissic crystalline complex:

Biotite granite--forms discordant stocks and phacoidal bodies normally less than a square mile in area, sills, and dikes. Absent in northwest quarter of quadrangle. Emplaced toward close of regional metamorphism. Typically medium-grained, nearly equigranular, and darker pink than other granitic rocks; contains 3-11 percent glistening black biotite that remains unaltered even in greatly weathered specimens; has relatively high radioactivity (background readings on a scintillation counter 1/2$2 \% 2$ times that of other granitic rocks). Some bodies, including the largest stock, exhibit no planar structure, but most are well foliated. Pegmatite filaments, a few inches apart, are common in the sills.

m

Migmatite--accompanies and grades into biotite granite in secs. 5 and 8 , southeastern part of the quadrangle. Migmatite is impure granite, locally crowded with slivers that are 2-6 inches long and rich in hornblende and biotite; like biotite granite it has relatively high radioactivity. Accessory mineral content appreciably higher in this migmatite than in adjacent granite from which it is derived. Other, more widespread, varieties of migmatite mapped with biotite gneiss unit.

d Porphyritic granite--forms 80-acre elongate body in central-eastern part of quadrangle and smaller lenses and dikes to the southwest. Foliation, strong in dikes and faint in larger bodies, roughly parallels contacts. Medium gray, with subtabular phenocrysts of microcline and plagioclase $1 / 4$ inch or less long in finegrained matrix of feldspar, quartz, and dark biotite; 3-5 percent sphene. Preceded biotite granite near close of metamorphic cycle.

Gabbroic gneiss and metamorphosed ultramafic rocks--tabular, elliptical, and amoeboid bodies lie within or adjoin hornblende gneiss, have transitional contacts with it, and are elongated with structural grain of enclosing rock; more abundant within hornblende gneiss in northwest and south parts of quadrangle than in the larger, central belt. Gabbroic facies generally only slightly banded, but locally conspicuously banded. Ultramafic rock is foliated only near contact. Commonly recognizable are large cleavage surfaces on hornblende, augite, and hypersthene; also variable plagioclase and olivine. Fine grained to very coarse grained; medium-grained, equigranular variety most abundant. Rusty Fe-stain in weathered hyper sthene and olivine imparts to many outcrops a brown tone unlike adjoining gray-black hornblende gneiss. In some outcrops, however, gabbroic facies closely resembles hornblende gneiss. Serpentinization is slight to moderate and generally confined to olivine. Converted to vermiculite where hydrother mally altered. Thin sections reveal ophitic and corona textures of igneous type.

f Charnockitic gneiss--quartzo-feldspathic rock characterized by hypersthene lies within northeast-trending zone of exceptionally contorted rock, 1-3 miles wide, that is terminated by Ilse fault. Compositional facies range from quartz dioritic to granitic.

The more mafic facies is particularly distinctive and is most representative of unit; forms layers and erratically ramifying masses of indefinite shape in hornblende gneiss; locally contains sparse layers of granite gneiss. This facies is dull brown, medium grained, and subequigranular; normally exhibits little planar structure, locally well banded; and offhand looks like impure granite but may readily be recognized by (1) greasy luster and gray-brown feldspar, (2) sooty black manganese that coats grains and fills cracks in outermost few inches of weathered rock, (3) lack of pink tones on weathered surfaces, and (4) prominent twinning striations on plagioclase feldspar.

Felsic facies approaches granite in appearance and mineralogy, and invariably is associated with granitic gneiss with or without hornblende gneiss. Brown greasy feldspar and sooty black films are less conspicuous than in the more mafic facies.

a Alaskitic granite gneiss--most abundant granitic rock. Concordant in thousands of sills, but intrudes gneisses in a few places. Less than a foot to about 500 feet thick. Pegmatite layers are common. Foliation moderately weak at most places but ranges from almost nil to strong, more conspicuous with increase in mafic minerals.

Typically pale pink, medium to fine grained, equigranular, and somewhat sugary looking. Two-feldspar granite consists of microcline more abundant than oligoclase, about one-third quartz. Magnetite and biotite, commonly the only dark minerals, together are generally about 1 percent of rock. Content of accessory minerals very sparse. Weathers more angular than other granites. Radioactivity on scintillation counter is generally nearly twice that of hornblende gneiss. Scattered layers contain relict garnet and, very rarely, sillimanite. Is source of granitic component of much migmatite included in biotite gneiss unit.

p Quartz monzonite gneiss--conformable lenses and sills about 5-300 feet thick and up to half a mile long, many with migmatite extending out for as much as several hundred feet from ends. At one place this rock is intruded by alaskitic 
granite gneiss. Typically pink and mediumgrained with many subparallel, coarser tabular feldspars; weathers more rapidly and has appreciably less quartz and more biotite than alaskitic granite gneiss. Coarse-grained feldspar-rich lamellae comprise 5-10 percent of most sills. Accessory minerals more abundant than in other granitic rocks.

Pegmatite--coarse to very coarse grained rock forms discordant mass in Silver Park. Pink quartz-feldspar rock is nearly devoid of other minerals except for local relict biotite and gar net. Several gray phacoidal bodies of pegmatite, some of which cover several acres, are interlayered with granite gneiss and hornblende gneiss over an area of several hundred acres extending beyond north limit of quadrangle near northeast corner. This pegmatite is mostly quartz and feldspar but locally may contain as much as several percent of magnetite, biotite, or hornblende. Concordant and slightly discordant pegmatites, too small to be mapped separately, are very common in granitic gneisses; they rarely contain minerals other than quartz and feldspar.

Hornblende gneiss--collective name for amphibolite, with or without pyroxene, hornblendeplagioclase gneiss, hornblende-pyroxeneplagioclase gneiss, and analogous rocks that contain biotite or microcline, or both; too intermixed to be divisible in mapping, these layered rocks in aggregate constitute nearly half the total volume of Precambrian rocks in quadrangle. Typically medium to dark gray, medium grained, and banded. Planar structure is due to slight differences in composition or texture of alternating laminations, or to planar orientation of dark minerals. Lineations, either subparallel mineral lentils or minor crinkles and folds, are visible at relatively few places, partly due to inferior outcrops; at some places hornblende lentils show preferred orientation in several directions. Mostly metasedimentary rocks but also includes metamorphosed sills and probable volcanic rock.

Plagioclase-quartz gneiss--three varieties, which together constitute about 3 percent of layered gneiss complex. Many occurrences are too small, or collectively too scarce to be mapped. One variety, which extends eastward from large S-shaped fold in secs. 17, 20, 21, T. 21 S., R. 71 W., is medium grained and ranges from whitish-gray rock with interlocking anhedral grains to pale-pink granular rock. Difficult to distinguish megascopically from closely associated alaskitic granite gneiss. Another variety, which forms concordant thin layers in hornblende gneiss in northwest part of quadrangle, is nearly white, medium to coarse grained, and contains almost no mafic minerals. ' Third variety forms concordant layers in hornblende gneiss in southeast part of quadrangle and encloses disoriented angular fragments and interlayers of hornblende gneiss; is light gray to greenish white, medium grained, and weakly foliated; contains as much as several percent hornblende and biotite.

b Biotite gneiss-- underlies 15-20 percent of quadrangle. Stratiform laminations and layers reflect compositional layers in antecedent, alumino-siliceous sediments. Distinctive garnetand sillimanite-rich layers serve as marker beds. Extremely distended and contorted plications and folds indicate biotite gneiss was least competent Precambrian unit during deformation.

Biotite-quartz-plagioclase paragneiss predominates. Typically is medium to light gray, medium grained, and strongly foliated; averages 5-10 percent biotite (maximum 40 percent), less than 5 percent K-feldspar, and sparse hornblende. Migmatite, which makes up about a fourth of unit, is in part paragneiss metasomatized by granites and in part a product of fractional melting; it tends to be pinkish gray, moderately coarse to medium grained, and has either lit-par-lit structure or "smeared" platy to swirly aspect; metasomatized variety contains more abundant accessory minerals than uncontaminated paragneiss.

Calc-silicate rock--lenses and layers, typically a few feet thick, mapped as marker beds or, where abundant enough, as a compound unit; some are large enough to be mapped as single units; isolated pods and lenses too small to be shown are fairly common in many layers within hornblende gneiss. Most common in north half of quadrangle, particularly in northeast quarter. Rock is dark to medium gray to white; dark facies associated with hornblende gneiss is most common. Calc-silicate rock is obscurely to conspicuously laminated and generally medium grained and granular. Common minerals, any one of which may predominate, are calcic plagioclase, red and brown garnet, hornblende, clinopyroxene, scapolite, calcite, and quartz. Sphene and magnetite are locally conspicuous. This metamorphosed limy sedimentary rock grades into plagioclase-quartz gneiss, hornblende gneiss, and quartzite.

Metaquartzite--widely distributed in quadrangle as thin layers that are quantitatively insignificant but confirm sedimentary origin of adjoining biotite gneiss and, less commonly, hornblende gneiss. Only longest are mapped as marker beds; few thicker than 20 feet and longer than several hundred feet. Rock generally laminated, and fine or medium grained; may be white, gray, red, green, or nearly black. Minerals other than quartz are garnet, magnetite, hornblende, and sillimanite.

u Gneisses undivided--bedrock exposures inadequate to determine types of gneiss present or their amount. Symbol also used in mixed units to indicate two or more additional rock types present. 
Nonmetamorphosed intrusive and related rocks:

A compound stock, several small plugs, and hundreds of dikes are older than the volcanic rocks but younger than the metamorphosed basement complex. Quartz syenite, syenite, and mafic alkalic rocks predominate. Explosion breccia and hydrothermally altered gneiss are products related to the intrusion of the alkalic rocks. Other nonmetamorphosed intrusive rocks include lamprophyre, peridotite, basalt, diabase, and gabbro.

The stock of alkalic rocks and an associated breccia extend into the quadrangle from the north. At least two cycles of magmatic differentiation are clearly displayed by the alkalic rocks. Each cycle began with quartz syenite and terminated with basaltic rock containing analcite and nepheline. Most, and possibly all, intrusive rocks within the compound stock have compositional equivalents among the dikes; all presumably originated from the same magmatic source.

Many basaltic and lamprophyre dikes are of uncertain age but are probably either Tertiary or Cambrian and hence $T €$ prefix for those dikes. Dikes known to be of Tertiary age are few. A Cambrian age is tentatively assigned to the alkalic complex because: (1) $\mathrm{K} / \mathrm{Ar}$ analyses of biotite from the rock within the stock indicate an age of 500 million years ( $₫ 5$ percent); (2) K/Ar analysis on whole rock from a phaneritic syenite dike gave $485 \pm 24$ million years: (3) K/Ar analyses of whole rock from two dikes containing completely devitrified syenite glass gave ages of 427 and 585 million years; (4) lead-alpha age determinations on two fractions of nonmetamict zircon from a sample of syenite collected in the stock gave ages of 580 and 601 million years (Jaffe and others, 1959, p. 127). (K/Ar analyses by R. F. Marvin, H. H. Thomas, Paul Elmore, and H. Smith, U.S. Geological Survey.) The $\mathrm{K} / \mathrm{Ar}$ ages given for the devitrified rocks probably reflect in part the age of their solidification as a glass and in part the age of devitrification.

The devitrified syenite glass, one of the youngest of the alkalic rocks, solidified at shallow depth. Its presence at levels now exposed precludes removal of a great amount of crystalline basement from this part of the range since its emplacement.

\section{Gneissic crystalline complex:}

Bedrock, except in the southwest corner of the quadrangle, is a crystalline complex of Precambrian gneisses cut by numerous dikes and many small plutons. The crystalline complex contains products of the high-grade metamorphism of sedimentary rocks and, possibly, interlayered tuffs and lavas, and products of magmatic intrusion, granitization, and differential melting. Rock typical of the granulite and amphibolite facies formed during the metamorphism. The resultant rocks are irregularly alternating layers of gneiss that pinch or swell, interfinger, or intergrade along and across strike. The thickness of individual layers rarely exceeds several tens of feet.
Variations in abundance of different gneisses in the interlayered rocks permit them to be divided into map units. In general, units designated by a single rock name are not less that 50 feet thick and are sequences in which one type of rock constitutes 80 percent or more of the material; those designated by two or more names are generally several hundred feet thick and are compound units in which each type of rock included is more than about 20 percent of the sequence. An exception is the biotite gneiss, whose single name is retained even where numerous small interlayers of hornblende-rich rock exceed 20 percent. Distinctive layers or zones less than 50 feet thick, notable either for lithologic or structural resons, were mapped as marker beds and are shown on the geologic map by an overprint pattern on the enclosing rock unit.

\section{Economic geology}

Hundreds of veins containing thorium and associated rare earths cut the Precambrian basement rocks and are potentially exploitable by small-scale mining methods. Nearly all veins trend northwesterly and are most numerous within a belt 5-6 miles wide that trends northwesterly across the quadrangle. The veins occupy steeply dipping zones of shattered and altered rock. Most are less than 10 feet wide, but a few are 50 feet wide. These radioactive veins can be traced for distances ranging from about 100 feet to nearly a mile. The veins contain, in addition to thorium and rare-earth minerals, brown and red oxides of iron, quartz, barite, carbonate minerals, and less commonly pyrite, galena, and fluorite. Thorite is the principal thorium mineral. Its erratic concentration makes prediction of grade hazardous. More than 100 selected samples from widespread localities in the region contained 0.2-12.5 percent $\mathrm{ThO}_{2}$. Rare-earth values generally coincide with an increase or decrease in thorium; however, a few samples with very low thorium content contained several percent of rare-earth oxides. The rare-earth oxides content in the 70 samples analyzed averages about a third that of thorium oxide. Production of thorium ore (mostly in 1957-58) a mounts to about a thousand tons mined from shallow openings. Two shipments of hand-cobbed ore from one property totaled 2,600 pounds and averaged 24 percent $\mathrm{ThO}_{2}$. Any significant futureproduction of thorium from these veins will depend on increased demand for that metal, and may to some extent depend on demand for rare earths.

The Bassick mine on Mount Tyndall has a recorded gold production of about $\$ 1,500,000$ (M. H. Bergendahl, U.S. Geol. Survey, oral commun., 1965), from tellurides among boulders in a breccia pipe penetrating volcanic rock. The production of precious and base metals from other nearby mines within the quadrangle is not known but presumably was small. Any appreciable production of these metals from this area In the future will be keyed to advances in exploration and mining techniques or in the prices of precious metals. 
A few thousand tons of barite were produced in the early 1930's from several veins, but because of their small size they hold little promise of any further production. Many small and mostly low-grade vermiculite deposits, all in hydrothermally altered gabbroic and ultramafic rock were found during the course of mapping. Very limited mining of a few vermiculite deposits coincided with the exploitation of the nearby barite deposits. Further production by small-scale operations is expected with the steadily increasing demand for vermiculite.

\section{Literature cited}

Christman, R. A., Brock, M. R., Pearson, R. C., and Singewald, Q. D., 1959, Geology and thorium deposits of the Wet Mountains, Colorado, a progress report: U.S. Geol. Survey Bull. 1072-H, p. 491-535.

Jaffe, H. W., Gottfried, David, Waring, C. L., and Worthing, H. W., 1959, Lead-alpha age determinations of accessory minerals of igneous rocks (19531957): U.S. Geol. Survey Bull. 1097-B, p. 65-148. 
